\title{
EFEKTIVITAS PENGGUNAAN MEDIA VIDEO KARTUN ANIMASI DAN POWER POINT TERHADAP PENGETAHUAN TENTANG KEBERSIHAN GIGI DAN MULUT SDI RADEN PAKU SURABAYA
}

\author{
Ihda Diah Rahmawati ${ }^{1}$, Endang Purwaningsih ${ }^{2}$, Soesilaningtyas ${ }^{3}$ \\ ${ }^{123}$ Jurusan Keperawatan Gigi Politeknik Kesehatan Kementerian Kesehatan Surabaya \\ Email :diah.ihda@yahoo.com
}

\begin{tabular}{|c|c|}
\hline & ABSTRAK \\
\hline & Kesehatan gigi dan mulut anak di Indonesia masih sangat rendah \\
\hline \multirow{10}{*}{$\begin{array}{l}\text { Kata Kunci : } \\
\text { Pengetahuan Kesehatan Gigi, } \\
\text { Media Video Kartun Animasi, } \\
\text { Power Point. }\end{array}$} & $\begin{array}{l}\text { sehingga perlu mendapatkan perhatian yang serius dari tenaga } \\
\text { kesehatan. Masalah dalam penelitian ini vaitu besarnva skor indeks }\end{array}$ \\
\hline & debris pada siswa kelas 3 SDI Raden Paku Surabaya. Penelitian ini \\
\hline & bertujuan untuk mengetahui efektivitas penggunaan media video \\
\hline & kartun animasi dan power point terhadap pengetahuan tentang \\
\hline & kebersihan gigi dan mulut pada siswa kelas SDI Raden Paku \\
\hline & Surabaya tahun 2020. Jenis penelitian adalah penelitian eksperimen. \\
\hline & $\begin{array}{l}\text { Penelitian ini menggunakan rancangan pre eksperimen dengan } \\
\text { desain Two Group Pretest Postest. Penelitian ini menggunakan teknik }\end{array}$ \\
\hline & simple random sampling. Jumlah sampel 56 siswa. Metode \\
\hline & $\begin{array}{l}\text { pengumpulan data menggunakan kuesioner. Teknik analisa data } \\
\text { menggunakan uji Mann Whitney. Hasil penelitian yaitu tidak terdapat } \\
\text { perbedaan yang signifikan antara hasil pengetahuan kelas } 3 \mathrm{~A} \text { dan } 3 \mathrm{~B} \\
\text { menggunakan media video kartun animasi dan power point. }\end{array}$ \\
\hline & ABSTRCT \\
\hline
\end{tabular}

Key word:

Dental Health Knowledge, Animated Cartoon Video Media, Power Point
Introduction: Dental and oral health of children in Indonesia is still very low so it needs to get serious attention from health workers. The problem in this study is the large debris index score in grade 3 students of SDI Raden Paku Surabaya. This study aims to determine the effectiveness of the use of animated cartoon and video media power point of knowledge about dental and oral hygiene in Raden Paku Surabaya Elementary School students in 2020. This type of research is experimental research.This study use sapre-experimental design with a designTwo Group Pretest Postest. This research uses technique simple random sampling. The number of samples was 56 students. The data collection method uses aquestionnaire. Data analysis techniques using the test Mann Whitney. The results of the study are that there is no significant difference between the results of class $3 \mathrm{~A}$ and $3 \mathrm{~B}$ knowledge using animated cartoon and video media power point.

\section{PENDAHULUAN}

Kesehatan gigi dan mulut anak di Indonesia masih sangat rendah sehingga perlu mendapatkan perhatian yang serius dari tenaga kesehatan. Kesehatan gigi dan mulut belum menjadi prioritas bagi sebagian masyarakat Indonesia (Abdullah,2018). Kesehatan gigi dan mulut merupakan hal yang penting dalam kehidupan setiap individu termasuk pada anak, karena gigi dan gusi yang rusak dan tidak dirawat akan 
menyebabkan rasa sakit, gangguan pengunyahan, dan dapat mengganggu kesehatan tubuh lainnya. Masalah gigi dan mulut pada anak dapat berpengaruh pada pertumbuhan dan perkembangan anak. Kondisi kesehatan gigi susu akan menentukan pertumbuhan gigi permanen pada anak (Putri A., 2016, cit. Kantohe R.,dkk.,2016).

Salah satu penyakit yang sering terjadi pada anak sekolah dasar adalah karies gigi.Karies gigi merupakan suatu penyakit jaringan gigi yang ditandai dengan kerusakan jaringan, dimulai dari permukaan gigi (ceruk, fisura, dan daerah interproksimal) yang meluas sampai ke arah pulpa. Gigi dengan fisur yang dalam mengakibatkan sisa- sisa makanan mudah melekat dan bertahan, sehingga produksi asam oleh bakteri akan berlangsung dengan cepat dan menimbulkan karies gigi (Tarigan, 2012).

Berdasarkan hasil Rikesdas 2018 provinsi Jawa Timur dijelaskan bahwa proporsi masalah gigi dan mulut sebesar 54,22 \% mengalami masalah pada gigi, sedangkan yang mendapatkan pelayanan kesehatan gigi oleh tenaga medis hanya 9,76 \% dan proporsi perilaku waktu menyikat gigiyang benar pada anak usia 3 tahun ke atas di provinsi Jawa Timur 2018 hanya 1.83 \% (Kemenkes RI, 2018).

Menurut profil kesehatan Jawa Timur 2017 berdasarkan hasil pemeriksaan kesehatan gigi untuk siswa SD/MI di kota Surabaya yang memerlukan perawatan gigi sebesar 141.487 siswa, dan yang mendapatkan perawatan gigi sebanyak 40.434 siswa dari 18.969 laki-laki dan 21.465 perempuan, hanya $28.6 \%$ yang mendapatkan perawatan, sedangkan yang memerlukan perawatan sebesar $141.487 \quad$ siswa.Apabila dibandingkan dengan profil kesehatan Jawa Timur 2016 yang memerlukan perawatan gigi sebesar 68.413 siswa, dan yang mendapatkan perawatan gigi sebanyak 49.548, hanya $72.4 \%$ yang mendapatkan perawatan sedangkan yang memerlukan perawatan sebesar 68.413 siswa (Kemenkes RI, 2017).

Kebersihan gigi dan mulut dapat diukur menggunakan kriteria Oral Hygiene Index Simplified (OHI-S) yang dilakukan dengan mengukur enam permukaan gigi. Gigi yang diperiksa adalah gigi molar dengan gigi incisivus kanan dan kiri pada rahang atas dan rahang bawah. Pengukuran OHI-S merupakan kombinasi anatara Debris Index Simplified (DI-S) dan Calculus Index Simplified (CI-S). Pengukuran debris indeks dengan kriteria: Baik $(0-0,6)$, Sedang $(0,7-1,8)$, dan Buruk $(1,9-3,0)$. Nilai standart Oral Hygiene Index Simplified yaitu Baik $(0-1,2)$, Sedang $(1,3-3,0)$, dan Buruk $(3,1-6,0)$ (Greene JC., Tth, dkk., cit. Ermawati, 2016).

Berdasarkan survey awal pada tanggal 16 November 2019 mengenai kebersihan gigi dan mulut terhadap 20 siswa kelas 3 di Sekolah Dasar Islam Raden Paku Surabaya di jalan Klampis Ngasem No. 88A, Klampis Ngasem, Kecamatan Sukolilo, Kota Surabaya, dengan skor indeks debris yaitu 1,92 yang termasuk kategori buruk.

Status ekonomi seseorang memberi dampak pada pemenuhan kebutuhan keluarga, semakin tinggi status ekonomi seseorang semakin mampu memenuhi kebutuhan hidupnya, termasuk memilih bentuk pelayanan kesehatan yang berkualitas (Budiharto, 2008, cit. Haryani 2017), sebaliknya orang dengan tingkat ekonomi rendah akan lebih berkonsentrasi terhadap pemenuhan kebutuhan dasar yang menunjang kehidupannya, hal ini berdampak pada perhatian terhadap kesehatan diri dan 
keluarga. Status ekonomi juga mempengaruhi kondisi kesehatan mulut seseorang, sebagai salah satu sarana kemampuan dalam pemeliharaan kesehatan gigi dan mulut (Moreira RS., dkk., 2015, cit.Haryani 2017).

Usia anak sekolah merupakan usia kelompok yang rentan terhadap penyakit gigi dan mulut, karena pada umumnya kelompok usia sekolah khususnya pada anak sekolah dasar, cenderung mempunyai kebiasaan yang kurang mendukung terciptanya kebersihan gigi dan mulut yang baik (Pontonuwu, dkk.,2013, cit. Pradita, dkk., 2016). Upaya meningkatkan pengetahuan tentang pemeliharaan kebersihan gigi dan mulut dapat dilakukan melalui pendidikan kesehatan gigi dan mulut. Pendidikan kesehatan gigi dan mulut merupakan suatu usaha yang dapat mempengaruhi individu untuk memiliki pengetahuan tentang menjaga kebersihan gigi dan mulut yang baik (Artini S., dkk., 2001, cit. Tandilangi, dkk., 2016).

Berdasarkan hasil analisis penelitian yang pernah dilakukan oleh Meartriecs Tandilangi pada tahun 2016 tentang efektivitas dental health education dengan media animasi kartun terhadap perubahan perilaku kesehatan gigi dan mulut Siswa SD Advent 02 Sario Manado, didapatkan bahwa media animasi kartun mempunyai kemampuan besar untuk menarik perhatian dan memengaruhi sikap maupun tingkah laku (Tandilangi, 2016). Penelitian lain yang pernah dilakukan oleh Lala Budi Fitriana pada tahun 2019 tentang Studi komparatif pengetahuan orang tua tentang temper tantrum yang diberikan pendidikan kesehatan dengan media power point dan flip chart, didapatkan bahwa media pembelajaran menggunakan power point dan flip chart sama- sama efektif dalam meningkatkan pengetahuan (Fitriana, 2019).

\section{METODE}

Jenis penelitian yang akan dilakukan adalah Quasi Experimental Design. Penelitian ini menggunakan rancangan dengan desain Two Group Pretest Postest. Penelitian ini dilakukan pada bulan November 2019 - Maret 2020. Sasaran penelitian ini adalah siswa kelas 3A dan 3B SDI Raden Paku Surabaya Metode pengumpulan data adalah kuesioner untuk mengukur pengetahuan tentang kebersihan gigi dan mulut. Data yang diperoleh dianalisis menggunakan uji Mann Whitney

\section{HASIL DAN PEMBAHASAN}

Responden dalam penelitian ini adalah siswa kelas 3A dan 3B di SDI Raden Paku Surabaya yang berjumlah 64 siswa. Pengambilan data pada penelitian ini menggunakan instrumen kuesioner yang terdiri dari 15 item. Skor penilaian yaitu nilai 1 untuk jawaban benar dan nilai 0 untuk jawaban salah. Hasil penelitian tersebut dapat dilihat pada tabel berikut: 
Home page: http://ejurnal.poltekkestasikmalaya.ac.id/index.php/jikg/index

Tabel 1 Uji Normalitas Data Pengetahuan Tentang Kebersihan Gigi dan Mulut Sebelum dan Sesudah Menggunakan Media Video Kartun Animasi Pada Siswa Kelas 3A SDI Raden Paku Surabaya

\begin{tabular}{|l|l|l|}
\hline Media Penyuluhan & $\begin{array}{c}\text { Jumlah } \\
\text { Siswa }\end{array}$ & $\begin{array}{c}\text { Shapiro- } \\
\text { Wilk }\end{array}$ \\
\hline Sebelum Video & 28 & 0,001 \\
\hline Sesudah Video & 28 & 0,001 \\
\hline
\end{tabular}

Berdasarkan table 1 hasil yang diperoleh adalah data berdistribusi tidak normal karena nilai signifikansi $<0,05$ yaitu sebelum dan sesudah dilakukan penyuluhan menggunakan video kartun animasi nilai signifikansi yang diperoleh yaitu 0,001.

Tabel 2 Uji Normalitas Data Pengetahuan Tentang Kebersihan Gigi dan Mulut Sebelum dan Sesudah Menggunakan Media Power Point Pada Siswa Kelas 3A SDI Raden Paku Surabaya

\begin{tabular}{|l|l|l|}
\hline Media Penyuluhan & $\begin{array}{l}\text { Jumlah } \\
\text { Siswa }\end{array}$ & $\begin{array}{l}\text { Shapiro- } \\
\text { Wilk }\end{array}$ \\
\hline Sebelum PPT & 28 & 0,006 \\
\hline SesudahPPT & 28 & 0,001 \\
\hline
\end{tabular}

Berdasarkan tabel 2 hasil yang diperoleh adalah data berdistribusi tidak normal karena nilai signifikansi $<0,05$ yaitu sebelum dilakukan penyuluhan menggunakan power point nilai sig yang diperoleh yaitu 0,006 dan sesudah dilakukan penyuluhan menggunakan power point nilai signifikansi yang diperoleh yaitu 0,001 .

Tabel 3 Analisis Pengetahuan Tentang Kebersihan Gigi dan Mulut Sebelum dan Sesudah Menggunakan Media Video Kartun Animasi Pada Siswa Kelas 3A SDI Raden Paku Surabaya

\begin{tabular}{|c|c|l|}
\hline $\begin{array}{c}\text { Media } \\
\text { Penyulu } \\
\text { han }\end{array}$ & $\begin{array}{c}\text { Jumlah } \\
\text { Siswa }\end{array}$ & Rata-Rata \\
\hline Sebelum Video & 28 & 60 \\
\hline Sesudah Video & 28 & 88,571 \\
\hline
\end{tabular}

Berdasarkan tabel 3 tersebut bahwa pengetahuan tentang kebersihan gigi dan mulut sebelum dan sesudah menggunakan media video kartun animasi terdapat perbedaan rata-rata nilai pengetahuan yaitu sebelum dilakukan penyuluhan menggunakan media video kartun animasi nilai rata-rata pengetahuan 60 , sedangkan sesudah diberi penyuluhan menggunakan video kartun animasi nilai rata-rata pengetahuan menjadi 88,571 dengan selesih nilai rata-rata pengetahuan sebelum dan sesudah penyuluhan menggunakan media video kartun animasi adalah 28,571.

Tabel 4 Analisis Pengetahuan Tentang Kebersihan Gigi dan Mulut Sebelum dan Sesudah Menggunakan Media Power Point Pada Siswa Kelas 3B SDI Raden Paku Surabaya

\begin{tabular}{|l|l|l|}
\hline Media Penyuluhan & $\begin{array}{c}\text { Jumlah } \\
\text { Siswa }\end{array}$ & Rata-Rata \\
\hline Sebelum Power Point & 28 & 60 \\
\hline Sesudah Power Point & 28 & 83,64 \\
\hline
\end{tabular}


Berdasarkan tabel 4 tersebut bahwa pengetahuan tentang kebersihan gigi dan mulut sebelum dan sesudah menggunakan media Power Point terdapat perbedaan rata-rata nilai pengetahuan yaitu sebelum dilakukan penyuluhan menggunakan media Power Point nilai rata-rata pengetahuan 60 , sedangkan sesudah diberi penyuluhan menggunakan Power Point nilai rata-rata pengetahuan menjadi 83,64 dengan selesih nilai rata-rata pengetahuan sebelum dan sesudah penyuluhan menggunakan media Power Point adalah 23,64.

Tabel 5 Efektivitas Penggunaan Media Video Kartun Animasi dan Power Point Terhadap Pengetahuan Tentang Kebersihan Gigi dan Mulut Siswa Kelas 3 SDI Raden Paku Surabaya

\begin{tabular}{|l|l|l|l|}
\hline $\begin{array}{c}\text { Media } \\
\text { Penyuluhan }\end{array}$ & $\begin{array}{c}\text { Jumlah } \\
\text { Siswa }\end{array}$ & \multicolumn{1}{|c|}{$\begin{array}{c}\text { Rata- } \\
\text { Rata }\end{array}$} & P.Value \\
\hline $\begin{array}{l}\text { Video } \\
\text { Animasi }\end{array}$ & 28 & 88,571 & 0,347 \\
\hline Power Point & 28 & 83,64 & \\
\hline
\end{tabular}

Berdasarkan hasil perhitungan dengan SPSS yang menggunakan uji Mann Whitney, diperoleh angka significancy yaitu0,347, karena nilai $\mathrm{p}>0,05$ maka tidak terdapat perbedaan yang signifikan antara hasil pengetahuan kelas 3A dan 3B menggunakan media video kartun animasi dan power point.

\section{PEMBAHASAN}

\section{Hasil Pengetahuan Tentang Kebersihan Gigi dan Mulut Sebelum Dilakukan Penyuluhan Menggunakan Media Video Kartun Animasi}

Berdasarkan hasil analisa data menunjukkan bahwa pengetahuan tentang kebersihan gigi dan mulut sebelum dilakukan penyuluhan menggunakan media video animasi pada siswa kelas 3A SDI Raden Paku Surabaya tahun 2020 termasuk kategori kurang, karena hal ini dipengaruhi oleh media dan metode yang digunakan dalam pendidikan kesehatan gigi yang diberikan, diketahui bahwa pengetahuan responden terhadap kebersihan gigi dan mulut sebelum dilakukan penyuluhan menggunakan media video kartun animasi dengan rata-rata pengetahuan tentang frekuensi dan waktu menyikat gigi dalam kategori "kurang". Hal ini menunjukkan responden kurang memenuhi standar yang diharapkan karena siswa kelas 3A belum pernah mendapatkan pendidikan tentang kebersihan gigi dan mulut secara khusus sebelumnya sehingga respon yang ditimbulkan oleh responden kurang yang menyebabkan rata-rata banyak yang belum mengetahui tentang frekuensi dan waktu menyikat gigi yang baik dan benar, karena frekuensi dan waktu menyikat ini salah satu cara menjaga kebersihan gigi dan mulut

\section{Hasil Pengetahuan Tentang Kebersihan Gigi dan Mulut Sesudah Dilakukan Penyuluhan Menggunakan Media Video Kartun Animasi}

Berdasarkan hasil analisa data menunjukkan bahwa pengetahuan tentang kebersihan gigi dan mulut sesudah dilakukan penyuluhan menggunakan media video animasi 
pada siswa kelas 3A SDI Raden Paku Surabaya tahun 2020 termasuk kategori baik, karena hal ini dipengaruhi oleh media dan metode yang digunakan dalam pendidikan kesehatan gigi yang diberikan, bahwa pengetahuan responden terhadap kebersihan gigi dan mulut sesudah dilakukan penyuluhan menggunakan media video kartun animasi dalam kategori baik karena setiap pernyataan tentang kebersihan gigi dan mulut mengalami peningkatan pengetahuan, yaitu pengetahuan tentang akibat kurang menjaga kebersihan gigi dan mulut mengalami peningkatan pengetahuan dari kategori kurang menjadi baik. Pengetahuan tentang makanan yang berpengaruh terhadap kebersihan gigi mengalami peningkatan pengetahuan dari kategori cukup menjadi baik, pengetahuan tentang frekuesnsi dan waktu menyikat gigi mengalami peningkatan pengetahuan dari kategori kurang menjadi baik, pengetahuan tentang cara menyikat gigi mengalami peningkatan pengetahuan dari kategori kurang menjadi baik, pengetahuan tentang upaya memelihara tentang kebersihan gigi dan mulut mengalami peningkatan pengetahuan dari kategori cukup menjadi baik .

\section{Hasil Pengetahuan Tentang Kebersihan Gigi dan Mulut Sebelum Dilakukan Penyuluhan Menggunakan Media Power Point}

Hasil analisa data menunjukkan bahwa pengetahuan tentang kebersihan gigi dan mulut sebelum dilakukan penyuluhan menggunakan media power point pada siswa kelas 3B SDI Raden Paku Surabaya tahun 2020 termasuk kategori kurang, karena hal ini dipengaruhi oleh media dan metode yang digunakan dalam pendidikan kesehatan gigi yang diberikan, diketahui bahwa pengetahuan responden terhadap kebersihan gigi dan mulut sebelum dilakukan penyuluhan menggunakan media power point dengan rata-rata pengetahuan tentang frekuensi dan waktu menyikat gigi dalam kategori "kurang". Hal ini menunjukkan bahwa siswa kelas 3A belum pernah ada penyuluhan tentang kebersihan gigi dan mulut menggunakan media yang menarik, karena Media ini berfungsi untuk mengakomodasikan siswa yang lemah dan lambat menerima dan memahami isi pelajaran (Arsyad, 2017), sehingga rata-rata banyak yang belum mengetahui tentang frekuensi dan waktu menyikat gigi yang baik dan benar.

\section{Hasil Pengetahuan Tentang Kebersihan Gigi dan Mulut Sesudah Dilakukan Penyuluhan Menggunakan Media Power Point}

Berdasarkan hasil analisa data menunjukkan bahwa pengetahuan tentang kebersihan gigi dan mulut sesudah dilakukan penyuluhan menggunakan media power point dengan metode ceramah pada siswa kelas 3B SDI Raden Paku Surabaya tahun 2020 termasuk kategori baik. Metode ceramah merupakan salah satu cara pendidikan kesehatan yang dilakukan dengan menerangkan atau menjelaskan sesuatu secara lisan disertai dengan tanya jawab, diskusi dengan kelompok dan pendengar serta dibantu dengan beberapa alat peraga (Tauchid, dkk., 2017), karena hal ini dipengaruhi oleh media dan metode yang digunakan dalam pendidikan kesehatan gigi yang diberikan.

\section{Efektivitas Penggunaan Media Video Kartun Animasi dan Media Power Point Terhadap Pengetahuan Tentang Kebersihan Gigi dan Mulut Pada Siswa Kelas 3 SDI Raden Paku Surabaya}

Hasil analisa data menunjukkan bahwa pengetahuan tentang kebersihan gigi dan mulut dengan menggunakan media video kartun animasi dan power point pada siswa 
kelas 3 SDI Raden Paku surabaya termasuk kategori baik, dan hasil analisis SPSS terdapat perbedaan antara media penyuluhan video animasi dan power point terhadap pengetahuan tentang kebersihan gigi pada siswa kelas 3 SDI Raden Paku Surabaya, karena hasil nilai rata-rata data kuesioner siswa kelas 3 SDI Raden Paku Surabaya bahwa setelah diberi penyuluhan menggunakan video kartun animasi lebih tinggi daripada setelah diberi penyuluhan menggunakan power point . Dengan demikian efektivitas penyuluhan menggunakan media video animasi dan power point terhadap pengetahuan tentang kebersihan gigi dan mulut sama-sama dapat meningkatkan pengetahuan siswa, akan tetapi apabila dilihat dari hasil rata-rata menunjukkan bahwa penggunaan media video kartun animasi lebih tinggi daripada penggunaan media power point.

Dalam penelitian ini penyuluhan tentang kebersihan gigi dan mulut menggunakan media power point dan media video kartun animasi, pada penyuluhan menggunakan power point kepada sasaran menggunakan metode one way metode yaitu ceramah. Metode ceramah merupakan salah satu cara pendidikan kesehatan yang dilakukan dengan menerangkan atau menjelaskan sesuatu secara lisan disertai dengan tanya jawab, diskusi dengan kelompok dan pendengar serta dibantu dengan beberapa alat peraga. (Tauchid, dkk., 2017).

Media power point termasuk media visual, Media berbasis visual (image atau perumpamaan) memegang peran yang sangat penting dalam proses belajar. Media visual dapat mempelancar pemahaman dan memperkuat ingatan. Media visual dapat juga menumbuhkan minat siswa yang dapat memberikan hubungan antara isi materi pelajaran dengan dunia nyata. Bentuk visual bisa berupa gambar representasi seperti gambar, lukisan, dan foto, diagram yang melukiskan hubungan-hubungan konsep, organisasi, dan struktur isi materi, grafik seperti tabel dan bagan (Arsyad, 2017). Media video kartun animasi memanfaatkan indera pendengaran dan penglihatan. Semakin banyak indera yang digunakan untuk merekam informasi, semakin besar kemungkinan memahami maksud informasi yang disampaikan. (Sadiman AS., 2014, cit. Tandilangi, dkk., 2016). Penyuluhan menggunakan video kartun animasi adalah pemberian pengetahuan berbentuk dua dimensi yang dibuat bergerak agar lebih menarik. Kartun animasi dapat menjadi sarana untuk menyampaikan pesan kepada orang banyak. Pesan-pesan yang digambarkan dalam sebuah animasi kartun diharapkan akan lebih diingat dan dipahami (Gozies, 2013, cit. Farikhatana, 2018).

Kelebihan media film kartun sebagai media pembelajaran yaitu: film animasi dapat menimbulkan kesan yang mendalam dalam diri guru atau siswa; suara dan gerakan yang ditampilkan adalah penggambaran kenyataan, sesuai dengan materi yang disajikan. Secara psikologis, film kartun dapat memenuhi unsur gerak bertukar-tukar, dan kontras, film kartun sebagai media mempuyai unggulan dalam suara, gambar kartun yang bergerak, garis dan simbol ditampilkan; film kartun dapat melengkapi pengalaman-pengalaman dasar dari siswa ketika berdiskusi, praktek. Film kartun merupakan pengganti alam sekitar dan bahkan menunjukkan objek yang secara normal tidak dapat dilihat; di samping mendorong dan meningkatkan motivasi, film kartun dapat menanamkan sikap dan segisegi afektif lainnya; film kartun yang bertema pendidikan mengandung nilai-nilai positif dapat mengundang pemikiran dan pembahasan dalam kelompok siswa; film kartun dapat ditunjukkan kepada kelompok 
besar atau kecil, kelompok yang heterogen, maupun perorangan (Efendi, 2002, cit. Putrama M., dkk., 2017).

\section{KESIMPULAN}

\section{SIMPULAN}

Berdasarkan penelitian yang telah dilakukan tentang efektivitas penggunaan media video kartun animasi dan power point terhadap pengetahuan tentang kebersihan gigi dan mulut pada siswa kelas 3 SDI Raden Paku Surabaya tahun 2020 disimpulkan bahwa:

1. Ada peningkatan pengetahuan tentang kebersihan gigi dan mulut sesudah diberi penyuluhan menggunakan media video kartun animasi pada siswa kelas 3A SDI Raden Paku Surabaya termasuk kategori baik.

2. Ada peningkatan pengetahuan tentang kebersihan gigi dan mulut sesudah diberi penyuluhan menggunakan media power point pada siswa kelas 3B SDI Raden Paku Surabaya termasuk kategori baik.

3. Tidak ada perbedaan efektivitas penyuluhan menggunakan media video animasi dan power point terhadap pengetahuan tentang kebersihan gigi dan mulut sama-sama dapat meningkatkan pengetahuan siswa, apabila dilihat dari hasil rata-rata menunjukkan bahwa penggunaan media video kartun animasi lebih tinggi daripada penggunaan media power point.

\section{SARAN}

Berdasarkan penelitian yang telah dilakukan tentang efektivitas penggunaan media video kartun animasi dan power point terhadap pengetahuan tentang kebersihan gigi dan mulut pada siswa kelas 3 SDI Raden Paku Surabaya tahun 2020.

1. Bagi SDI Raden Paku Surabaya

a. Diharapkan guru di Sekolah Dasar Islam Raden Paku Surabaya tetap memantau kesehatan dan kebersihan gigi siswa serta memberikan edukasi tentang kebersihan gigi dan mulut menggunakan media video kartun animasi kepada siswa.

b. Bekerjasama dengan petugas kesehatan terutama kesehatan gigi untuk memberikan pendidikan menggunakan video kartun animasi tentang kebersihan gigi dan mulut, sehingga kebersihan gigi dan mulut anak di sekolah menjadi terkontrol.

\section{Bagi Peneliti Selanjutnya}

Diharapkan peneliti selanjutnya dapat mengembangkan penelitian mengenai penggunaan media khususnya media video kartun animasi tentang kebersihan gigi dan mulut sejak dini, karena media sangat penting sebagai perantara untuk memberikan informasi yang menarik sehingga informasi yang disampaikan dimengerti oleh responden 


\section{DAFTAR PUSTAKA}

Abdullah, N. (2018). Hubungan Status Kesehatan Gigi Dan Mulut Anak Sekolah Dengan. Media Kesehatan Gigi, 17(1), 32.

Arikunto, S. 2010. Prosedur Penelitian Suatu Pendekatan Praktik. Rineka Cipta. Yogyakarta.

Arsyad, M. (2017). Media Pembelajaran. Jakarta: PT Raja Grafindo Persada.

Budiharto, S. (2009). Ilmu Perilaku Kesehatan dan Pendidikan Kesehatan Gigi. Jakarta: Buku Kedokteran EGC.

Dessy,N.dkk. (2016). Pemanfaatan Video Sebagai Media Pembelajaran Matematika SD/MI.Kalimantan.Jurnal Madrasah Ibtidaiyah, 2 (1).

Dinas Kesehatan Propinsi JawaTimur. (2017). Profil Kesehatan Propinsi Jawa Timur 2017. Nucleic Acids Research, 34(11), e77-e77.

Dinkes. (2016). Profil Kesehatan Jawa Timur tahun 2016. Provinsi Jawa Timur, Dinkes.

Djamil, D. (2017). Panduan Lengkap Kesehatan Gigi Keluarga (N. Laili, ed.). Solo.

Ermawati, T. (2016). Profil Kebersihan Dan Perilaku Menjaga Kesehatan Gigi Dan Mulut Pada Lansia Di Desa Darsono Kabupaten Jember. Ikesma, 12 (september 2016), 77-83.

Farikhatana, R. (2018). Perbedaan Sebelum dan Sesudah Penyuluhan Menggunakan Media Animasi Kartun Terhadap Peningkatan Pengetahuan Kesehatan Gigi dan Mulut. Surabaya.

Fitriana. L.B. dan Apriani. W. R. (2019). Studi Komparatif Pengetahuan Orang Tua Tentang Temper Tantrum yang diberikan Pendidikan Kesehatan dengan Media Power Point dan Flip Chart. Yogyakarta. Jurnal Ilmu Kesehatan. 10 (1).

Haryani, W.dkk. (2017). Pendidikan dan status ekonomi dengan kepatuhan perawatan gigi tiruan lepasan. Majalah Kedokteran Gigi Indonesia, 3(3), 42. https://doi.org/10.22146/majkedgiind.26806

Haq, Z. (2017). Penggunaan Komik Kesehatan Gigi Dalam Meningkatkan Pengetahuan Dan Kepercayaan Siswa Kelas V Sdn Martopuro 01 Kecamatan Purwosari Kabupaten Pasuruan.Jurnal PROMKES, 3(2), 124.https://doi.org/10.20473/jpk.v3.i2.2015.124-133

Jatmiko. E. D. Septian dan Safrilia. F. E. (2019). Perbedaan Edukasi Konsumsi Sayur dan Buah Pada Anak SD Menggunakan Metode Ceramah dengan Alat Peraga dan Media Audiovisual. Yogyakarta. Gizi indonesia. 42 (1). 53-60.

Kantohe, Z. R.dkk. (2016). Perbandingan efektivitas pendidikan kesehatan gigi 
Home page: http://ejurnal.poltekkestasikmalaya.ac.id/index.php/jikg/index

menggunakan media video dan flip chart terhadap peningkatan pengetahuan kesehatan gigi dan mulut anak. E-GIGI, 4(2), 712.https://doi.org/10.35790/eg.4.2.2016.13490

Kemenkes RI. (2012). Pedoman Usaha Kesehatan Gigi Sekolah. Jakarta.

Kemenkes RI.

Margareta, S. (2012). 101 Tips \& Terapi Gigi Putih dan Sehat. Jakarta.

Notoatmodjo, S. (2012). Metedogi Penelitian Kesehatan. Jakarta: PT RINEKA CIPTA.

Notoatmodjo, S. (2012). Promosi Kesehatan dan Perilaku Kesehatan. Jakarta: PT RINEKA CIPTA.

Prasasti I. (2016). Hubungan Peran Orang Tua Dalam Kebersihan Gigi dan Mulut dengan Karies Gigi pada Anak Pra Sekolah Di Taman Kanak-Kanak (TK) PGRI Kelurahan Ngresep Semarang. Semarang. UNDIP.

Prasetiowati, L. E. (2016). Efektifitas Buah Semangka dan Jambu Biji Terhadap Nilai OHI-S Pada Anak Usia 10-12 Tahun.Analis Kesehatan, 5 (1).

Putrama M., dkk. (2017). Film Seri Animasi 3D Belajar Bahasa Indonesia Bersama Made Sebagai Media Pembelajaran Bahasa Indonesia Untuk Penutur Asing di Undiksha. Kumpulan Artikel Mahasiswa Pendidikan Teknik Inforrmatika, 6(1).

Razi, P. dan Rosmawati, R. (2018). Perbandingan Efektivitas Edukasi Kesehatan Gigi Dengan Metode Bermain, Video Dan Boneka Dalam Meningkatkan Keterampilan.Jurnal Bahana Kesehatan Masyarakat, 2(2), 101-106.

Riki,R.(2015). Film Dokumenter Sebagai Sumber Belajar Siswa. Palembang. Institut Seni Indonesia Padangpanjang. Jurnal Ilmu Pengetahuan dan Karya Seni, 17(1).

Riskesdas. (2018). Hasil Utama Riskesdas Penyakit Tidak Menular 2018. Hasil Utama Riskesdas Penyakit Tidak Menular, 8.

Sipayung, T. M. dkk. (2018). Pengaruh Konsumsi Pir (Pyrus) terhadap Indeks Debris pada Siswa SD Garuda di Kota Manado. E-GIGI, 6(2), 51. https://doi.org/10.35790/eg.6.2.2018.19939

Setiari, L. S. dan Sulistyowati, M. (2018). Tindakan Pencegahan Karies Gigi Pada Siswa Sekolah Dasar Berdasarkan Teori Health Belief Model. Jurnal PROMKES, 5(1), 65. https://doi.org/10.20473/jpk.v5.i1.2017.65-76

Soesilaningtyas, (2018). The Effectiveness of The Story Book With Picture on Oral Health Knowledge of Deaf Students. Faculty Of Public Health. Airlangga University.

Tandilangi, M. dkk. (2016). Efektivitas dental health education dengan media animasi kartun terhadap perubahan perilaku kesehatan gigi dan mulut siswa 
Home page: http://ejurnal.poltekkestasikmalaya.ac.id/index.php/jikg/index

SD Advent 02 Sario Manado. E-GIGI. 4(2).

Tarigan, P. D. (2012). Karies Gigi. Jakarta: Buku Kedokteran EGC.

Tauchid, N. S.dkk. (2017). Buku Ajar Pendidikan Kesehatan Gigi. Jakarta: Buku Kedokteran EGC. 